2016, volume 5, issue 1

Ryszawska B. (2016). Sustainability transition needs sustainable finance. Copernican Journal of Finance \& Accounting, 5(1), 185-194. http://dx.doi.org/10.12775/CJFA.2016.011

\author{
Bożena RYSZAWSKA* \\ Wroclaw University of Economics
}

\title{
SUSTAINABILITY TRANSITION NEEDS SUSTAINABLE FINANCE
}

Keywords: sustainability transition, sustainable finance, climate finance, green finance.

J E L Classification: Q01, Q54, Q56, G23.

Abstract: Transition is a term used to describe conversion (evolution) from the existing model of economy and finance towards one based on increased social and environmental responsibility. The purpose of this study is to emphasise the role of sustainable finance in the sustainability transition process. The main thesis can be expressed as follows: the role of finance is changing from the dominant view rooted in neoclassical economic theory (to maximize profits, and shareholder wealth) towards one supporting sustainable development, green economy, low carbon economy also adaptation and mitigation of climate change. The article uses the multilevel perspective created by F.W. Geels effective in the analysis of the sustainability transition. Results of analysis: There is evidence that the old regime of finance destabilizes. Finances are slowly responding to new demand in sustainable economy to align with it.

\section{IIITRODUCTION}

Sustainability transition in conventional reception is associated with the process of multi-level transformation of the economic and socio-technological system intended to increase its environmental sustainability and social fairness.

Date of submission: February 29, 2016; date of acceptance: May 10, 2016.

* Contact information: bozena.ryszawska@ue.wroc.pl., Deparament of Public and International Finance, Wroclaw University of Economics, Komandorska 118/120, 53-345 Wroclaw, Poland, phone: +48713680646. 
This particular concept is typically evoked in the context of transition to green economy of low emission and resource efficiency, based on clean technologies and other solutions generally referred to as eco-innovation. Sustainability transition influence profoundly financial sector.

The present problems, both environmental (such as climatic changes, the loss of bio-diversity and depletion of natural resources) and social (mostly associated with steep inequalities in income distribution), present an enormous challenge to economic development. Those problems can only be faced by means of deep structural changes to the adopted production and consumption patterns. Changes of this scale can only be effected through concerted effort of various economic actors: companies, industry sectors, decision-makers, political powers, consumer groups, active civil societies, engineers, and scientists. In effect, the postulated transition should be interpreted as a complex and prolonged process involving a multitude of areas and actors (Geels 2011).

The purpose of this study is to emphasise the role of sustainable finance in the sustainability transition process. The main thesis can be expressed as follows: the role of finance is changing from the dominant view rooted in neoclassical economic theory (to maximize profits, and shareholder wealth) towards one supporting sustainable development, green economy, low carbon economy also adaptation and mitigation of climate change. We can call it a silent revolution in finance.

\section{THE RESEARCH METHODOLOGY AND THE COURSE OF THE RESEARCH PROCESS}

The article uses the multilevel perspective created by F.W. Geels effective in the analysis of the sustainability transition. The first section of this paper presents the most popular approaches to the sustainability transition at hand, as reported in professional literature. Section two presents characteristics of the various actors involved in the anticipated transformation of the economy. The third section discusses the emerging financial initiatives supporting sustainability transition and autor's view on sustainable financial system.

\section{INTERPRETATIONS OF THE SUSTAINABILITY TRANSITION CONCEPT}

The influx of crisis symptoms and problems in the economic, environmental, social and political spheres has gained pace with the outburst of the latest global financial crisis. The most profound effect was the acceleration of fundamen- 
tal systemic changes which - by their strongly voiced opposition to the existing system resulting in rapid generation of aggravated imbalance - naturally tends towards the sustainability transition (Loorbach i Lijnis Huffenreuter 2013).

The approach to understand sustainability transition is based on the assumption that the transformation is not a linear process but a joint effect of occurrences observed on three distinct levels: in niches - as areas associated with radical innovations; in the dominant economic, technological and social system (the existing patterns of production, consumption, management, and legislation - the socio-technical regime); in the external economic, social and technological environment (demographic trends, political ideologies, financial crises, social values, and macroeconomic principles - the socio-technical landscape).

The sustainability transition is an end result of all interactions that occur between processes on each of the above levels. In this view, niches are the environment involved in the initiation of changes with potential to accelerate changes in the dominant system, while processes observed in the external surrounding exert pressure upon the system. Destabilisation of the dominant system, in turn, forms windows of opportunity for further innovations generated at niche level (Geels 2013).

\section{SUSTAINABLE FINANCE, GREEN FINANCE, CLIMATE FINANCE SUPPORT SUSTAINABILITY TRANSITION}

Recent transformation of financial sectors is adopting itself to the new trend of greening finance. L. Dziawgo confirms it: financial market has been involved in supporting proecological transformation of the society and economy and, at the same time, it has been evolving slightly towards "greening" financial market. (Dziawgo 2014). The process is powerful and fast. Driving force of change is a renewable energy sector. A number of green markets have emerged as a result of increased public and private investments. They include: carbon finance, green stimulus funds, microfinance, green bonds, international and national climate funds, green infrastructure, real estate funds, socially responsible equity funds.

Sustainability transition is a multilevel process which means reaching goals of sustainable development, transforming economy towards green, low carbon, resource efficient and to combat climate change. This process is supported by sustainable finance, green finance and climate finance (table 1). 
Table 1. Sustainability transformation and finance

\begin{tabular}{|l|l|l|}
\hline \hline \multicolumn{1}{|c|}{ Goals } & \multicolumn{1}{|c|}{ Finance } \\
\hline \hline Sustainable development & Sustainable finance & \multirow{2}{*}{ Sustainable financial system } \\
\hline $\begin{array}{l}\text { Green economy, green growth, low } \\
\text { carbon, resource efficient economy }\end{array}$ & Green finance & \\
\cline { 1 - 2 } $\begin{array}{l}\text { Adaptation and Mitigation of Clima- } \\
\text { te change }\end{array}$ & Climate finance & \\
\hline \hline
\end{tabular}

S o u r c e : author`s own elaboration.

Sustainable finance were defined as finance supporting sustainable development in three combined dimensions: economic, environmental and social. It were defined after the first Earth Summit in Rio in 1992 by United Nation Environmental Program. Centre for Responsible Business says that: sustainable finance is the practice of creating economic and social value through financial models, products and markets that are sustainable over time (Centre for Responsible Business 2016). Simply sustainable finance can be referred as any of the financial institution's practices supporting and facilitating sustainable development (UNEPFI 2015).

The concept of green finance is not commonly defined. Generally it supports green growth and transition to green economy and reduces negative environmental outcomes. Green finance means investment in renewable energy, reduction of emission in industry, sustainable transport, recycling, organic agriculture, waste management, water management, eco-innovation, clean technology by public and private actors.

Climate finance is a new issue in an international debate. The aim of climate finance is to support adaptation to climate change and mitigation of climate change. It mean also financing a shift towards low emission and climateresilient development (Figure 1). Climate finance is a critical element of global climate policy. Effective mitigation of climate change will depend on a complex mix of public funds, private investment through carbon markets, and sophisticated national and global regulation, forest and energy policy, international development funding, international trade law, and coordinated tax policy (Stewart, Kingsbury, Rudyk 2009). 
Figure 1. Aligning the financial system with Sustainable Development

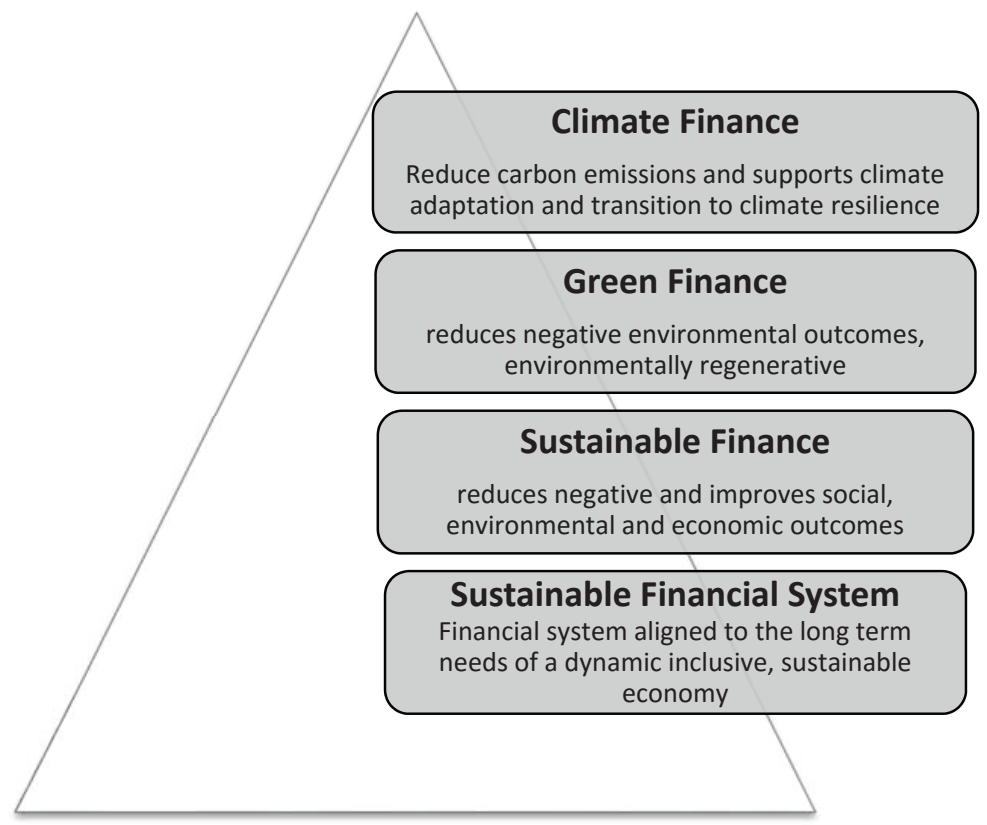

S o u r c e : UNEP, Aligning the financial system with Sustainable Development. The Coming Financial Climate, The Inquiry`s 4th Progress Report, United Nations Environment Programme, 2015b, p. 1.

Climate finance was a 'hot topic' in international climate negotiations in Paris in 2015. An historic agreement to combat climate change and unleash actions and investment towards a low carbon, resilient and sustainable future was agreed by 195 nations. (Green Climate Found 2016). The universal agreement's main aim is to keep a global temperature rise this century well below 2 degrees Celsius above pre-industrial levels. To reach these ambitious and important goals, appropriate financial flows will be put in place. Without adequate financial resources and investments countries can't sufficiently reduce GHG emissions and respond to a changing climate.

To sum up all presented kinds of finance facilitate sustainability transition and create a sustainable financial system, which creates, values, and transacts financial assets, in ways that shape real wealth to serve the long-term needs of an inclusive, environmentally sustainable economy (UNEP 2015c). A sustainable financial system plays three key roles to enable this transition a low-car- 
bon, climate resilient economy: (UNEP,2015b) first, it effectively recognizes the costs and risks of high-carbon and resource intensive assets; second, it allocates sufficient attractively priced capital to low-carbon, resource efficient assets; third, it ensures that financial institutions and consumers are resilient to climate shocks, including natural disasters.

\section{THE OUTCOME OF THE RESEARCH PROCESS AND CONCLUSIONS}

Transition towards sustainable financial system is a part of general concept of sustainability. Changes on the landscape level are obvious, starting from global financial crisis (questioning existing economic model and emphasizing negative role of financial markets), environmental and social crisis (damage of ecosystems, social inequalities), climate change, low carbon, green transformation of economy. This processes influence economic, political, social aspects of our lives. Simultaneously with new tendencies in landscape, the financial system is changing (on the periphery of economy, creating innovation`s niches). The old regime of finance destabilizes. Finances are slowly responding to new demand in sustainable economy to align with it (Figure 2).

Figure 2. Sustainable transformation in finance - multilevel perspective

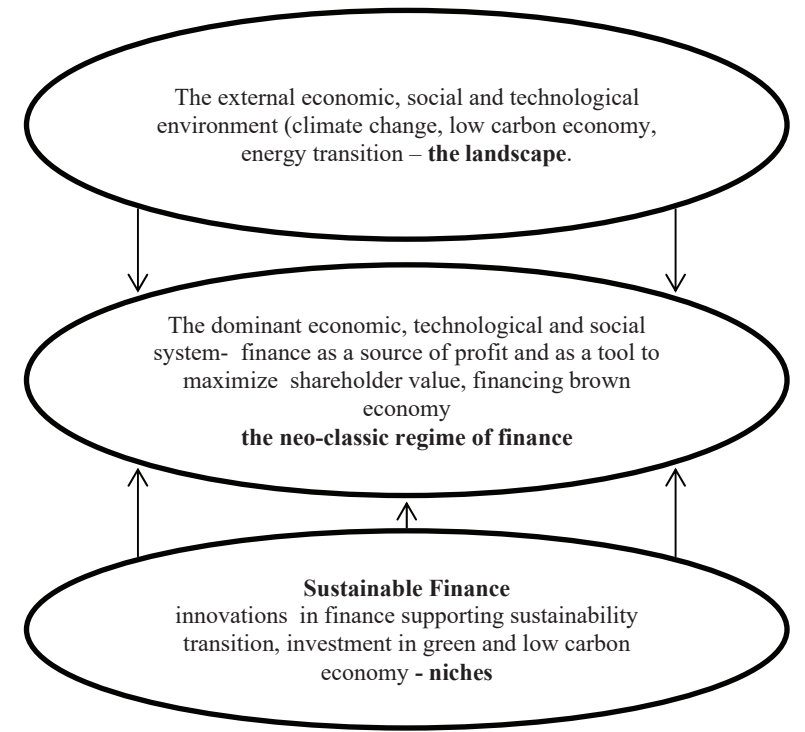

S o u r c e : author’s own elaboration. 
Authors of Positive Finance write: Transforming the economic model is extremely costly. We have to re-envision the allocation of capital in order to support social and technological innovations, to design and build sustainable infrastructure, and to finance the energy transition. Reinvented, finance could become a powerful lever for setting these transformations in motion. (Guez, Zaouati 2015). Recently many new sustainable initiatives emerged in finance: Green Climate Found and national climate founds. established as the investment vehicle for climate finance (USD 100 billion per year by 2020, from a variety of sources) (Green Climate Fund 2015b); New Energy Finance - Bloomberg (financial markets); National public finance - fiscal policy for green economy, budget's expenditures supporting green sectors, taxes, decreasing subsidies for harmful production, green public procurement, investment in green public infrastructure, researches and development expenditures for eco innovations and green technology; Carbon Finance - World Bank.

Renewable energy sector is driving force of sustainable economy therefore renewable energy finance is a agent of change in sustainable financial system. Common decision on the international level (COP Paris 2015) to reach $2^{\circ} \mathrm{C}$ goal to slow down climate change, projects that public and private investment in clean energy reach 329 bln $\$$ in 2015, 500 bln \$/year additionaly by 2020 and by 2030 additionally 1 trilion $\$$ a year after 2020 (New Energy Finance 2016) (CERES 2015).

Sustainability transition in finance is seen as the result of existing regimes which open up as a consequence of external shocks (climate change, energy transition, low carbon economy) and simultaneously bottom up innovations and new financial initiatives like climate finance, green finance, carbon finance. It is a structural change in financial system on many levels: international, public, corporate and household finance (table 2).

Table 2. Finance for sustainability - examples of actions

\begin{tabular}{|l|l|l|}
\hline \hline \multicolumn{1}{|c|}{ Levels } & \multicolumn{2}{|c|}{ Finance for sustainability } \\
\hline \hline International and global finance & $\begin{array}{l}\text { UN Finance, OECD Finance, interna- } \\
\text { tional development funding, World } \\
\text { Bank`s Finance }\end{array}$ & $\begin{array}{l}\text { General framework, guidelines, } \\
\text { Climate finance, Carbon Finance }\end{array}$ \\
\cline { 2 - 3 } & Financial markets & $\begin{array}{l}\text { Carbon markets, shares of green } \\
\text { companies, green bonds, global } \\
\text { financial investment, New Energy } \\
\text { Finance }\end{array}$ \\
\hline
\end{tabular}




\begin{tabular}{|c|c|c|}
\hline Levels & \multicolumn{2}{|c|}{ Finance for sustainability } \\
\hline \multirow[t]{3}{*}{ Public Finance } & European Union`s Finance & $\begin{array}{l}\text { Europe } 2020, \text { new financial per- } \\
\text { spective } 2014-20 \text {, structural funds } \\
\text { for green economy and agriculture, } \\
\text { encouraging member states to } \\
\text { invest in green sectors, adaptation } \\
\text { to climate change policy }\end{array}$ \\
\hline & National Public Finance & $\begin{array}{l}\text { National fiscal policy for green } \\
\text { economy, budget`s expenditures } \\
\text { supporting green sectors, taxes, } \\
\text { decreasing subsidies for harmful } \\
\text { production, green public procure- } \\
\text { ment, investment in green public } \\
\text { infrastructure, researches and } \\
\text { development expenditures for eco } \\
\text { innovations and green technology }\end{array}$ \\
\hline & Local Public finance & $\begin{array}{l}\text { Financing local green growth, gre- } \\
\text { en public procurement, domestic } \\
\text { low carbon economy and climate } \\
\text { finance }\end{array}$ \\
\hline \multirow[t]{2}{*}{ Private finance } & Corporate Finance & $\begin{array}{l}\text { Voluntary green purchasing, green } \\
\text { products and services, corporate } \\
\text { sustainability }\end{array}$ \\
\hline & Household finance & $\begin{array}{l}\text { Buying green products and services, } \\
\text { investing in green founds, renewa- } \\
\text { ble energy investment }\end{array}$ \\
\hline
\end{tabular}

S o u r c e : author`s own elaboration.

The consequences of sustainability transition in finance is a huge challenge for science to address all important issues, to help the audience to understand new process, to design survey, to create new models and tools to explain structure and function of sustainable finance system. Role of science is not only describe and analyze transformation but also predict future trends which has meaning for business, governments, financial markets, university education and society.

To conclude we can use words written by Mike Townsend, in his newest book The Quiet Revolution: We are in a new era. The systems, rules and behaviours that led to business success in the 21st century are no longer working. Since the onset of the longest and deepest financial crisis in living memory, capitalism is still suffering a crisis of liquidity, reliability and confidence. There is a huge question mark over whether our economic system will allow us to make the necessary transition to a more sustainable world or whether we are locked into a fatal collision course (Townsend 2016). 
A quiet revolution in finance is already underway. The role of science, governments, business and consumers is get aware about it and use this transformation for better future of the planet

\section{REFERENCES}

Centre for Responsible Business. (2016). Centre for Responsible Business, http://responsiblebusiness.haas.berkeley.edu/programs/sustainablefinance.html (accessed: 02.10.2016).

CERES. (2015). The Role of the Electric Sector in Achieving the Clean Trillion: Mapping The Gap, http://www.ceres.org/issues/clean-trillion (accessed: 02.10.2016).

Dziawgo, L. (2014). Greening financial market. Copernican Journal of Finance \& Accounting, 3(2). http://dx.doi.org/10.12775/CJFA.2014.014.

Farla, J., Markard J., Raven R., \& Coenen, L. (2012). Sustainability transitions in the making: A closer look at actors, strategies and resources. Technol. Forecast. Soc. Change, 79(6). http://dx.doi.org/10.1016/j.techfore.2012.02.001.

Geels, F. (2011). The multi-level perspective on sustainability transitions: Responses to sev-en criticisms. Environmental Innovation and Societal Transitions(1). http:// dx.doi.org/10.1016/j.eist.2011.02.002.

Geels, F. (2013). The impact of the financial-economic crisis on sustainability transitions: Financial investment governance and public discourse. Environmental Innovation and Societal Transitions no 6, 67-95. http://dx.doi.org/10.1016/j. eist.2012.11.004.

Green Climate Found . (2016). Green Climate Found: imate.fund/-/unfccc-paris-agreementon-climate-change?inheritRedirect=true\&redirect=\%2Fhome (accessed: 02.10.2016).

Green Climate Fund. (2015b). Investment Opportunities for the Green Climate Fund. Elements Issue 02 | November 2015,(2).

Guez, H., \& Zaouati, P. (2015). Positive Finance. A Toolkit for Responsible Transformation, London: Greenleaf Publishing.

Loorbach, D., \& Lijnis Huffenreuter, R. (2013). Exploring the economic crisis from a transition management perspective. Environmental Innovation and Societal Transitions no 6, 35-46. http://dx.doi.org/10.1016/j.eist.2013.01.003.

McIntosh, M. (2013). The Necessary Transition. The Journey towards the Sustainable Enterprise Economy. London: Greenleaf Publishing.

Magnuszewski, P., Sodomkova, K., Slob, A., Muro, M., Sendzimir, J., \& Pahl-Wost, C. (2010). Report on conceptual framework for science-policy barriers and bridges. Retrieved 05 15, 2013, from Policy and science inteactions, http://www.psiconnect. eu/ (accessed: 15.05.2016).

New Energy Finance. (2016). New Energy Finance, http://about.bnef.com/ (accessed: 02.10.2016).

OECD. (2011). Towards Green Growth. OECD. 
Røpke, I. (2013). Sustainability transitions in the perspective of ecological macroeconomics. The 10th Biennial Conference of the European Society for Ecological Economics. Lille, France: European Society for Ecological Economics.

Stewart, R., Kingsbury, B., \& Rudyk, B. (2009). Climate Finance: Regulatory and Funding Strategies for Climate Change and Global Development, New York: NYU Press.

Townsend, M. (2016). The Quiet Revolution: Towards a Sustainable Economy. London: Greenleaf Publishing .

UNEP. (2015). Aligning the financial system with Sustainable Development. The Coming Financial Climate, The Inquiry`s 4th Progress Report. UNEP.

UNEP. (2015b). Aligning the financial system with Sustainable Development. The Coming Financial Climate, The Inquiry`s 4th Progress Report, United Nations Environment Programme, UNEP, http://www.unep.org (accessed: 02.10.2016).

UNEP. (2015c). The Financial System We Need, Inquiry: Design of a Sustainable Financial System. Geneva.

UNEPFI. (2015). State of Green Finance in the UAE UAE Green Agenda 2015-2030 ,The first national survey on contributions of financial institutions to Green Economy, UNEP, http://www.unepfi.org/ (accessed: 02.10.2016). 